\title{
Research on the Development of Environmental Accounting in China Ting Guo ${ }^{1}$ a \\ ${ }^{1}$ School of Management, Yulin University, China, 719000 \\ a536969980@qq.com
}

\begin{abstract}
Keywords: Environmental accounting; Environmental resources; Environmental pollution; Environmental protection; Sustainable development
\end{abstract}

\begin{abstract}
In recent years the waste of resources is serious, environment worsening, human survival environment is a serious threat. In this case the environment accounting arises at the historic moment. Environmental accounting caused great attention world, in foreign development earlier, but in our country late start, the development is relatively slow. This paper aims to study of environmental accounting in China's development is slow reason, in which the author reasonable countermeasures to promote environmental accounting in the development of our country. Based on the environmental accounting as the main research object, the research scope of concentrated in environmental accounting in China slow development of reason, and should take the rational countermeasures.
\end{abstract}

\section{Introduction}

Since the reform and opening up, China's economic growth has been in a high input, high consumption, low efficiency of the extension and extensive economic growth mode. Our country every year because of the waste of resources, environmental pollution and ecological destruction caused enormous economic losses. It makes us the traditional accounting system questioned, with tangible loss an independent enterprise to calculate cost, or from the basis of all social loss up to calculate cost. Environmental accounting is the natural resources, human resources and ecological resources into the enterprise accounting system, so that the natural capital and social benefits in the enterprise activities through the accounting work reflected, resource utilization and environmental costs for society the evaluation of enterprises, so as to effectively guide and manage to walk the road of environmental protection.

\section{The Present Situation of the Development of Environmental Accounting}

The laws and regulations of environmental protection. China attaches great importance to environmental issues, promulgated a series of resource management and environmental protection laws and regulations, in the practice of environmental protection in the formation of the "polluter governance, who develops protection, who uses whom compensation, who destroys the" recovery of environmental policy, as early as September 1979, China had promulgated "People's Republic of China environmental protection law (Trial) 1994 years, the Chinese government formulated a programmatic document" Chinese twenty-first Century agenda -- population, resources and environment will determine the sustainable development of the white paper ", for the realization of our society, the basic strategy of the coordinated development of economy and environment. However, China has not enacted specific legal provisions of environmental accounting this leads to the units and enterprises in the processing of environmental accounting related issues, there is no specific reference standards and regulations, the environmental accounting without substantial development.

Environmental accounting and information. The importance of environmental accounting recognized by more and more people, the theory of environmental accounting research has become more perfect, however, because of the lack of scientific and quantitative methods and feasible index system, the monetary measurement, information disclosure, environmental cost and income information such as the lack of operability of the method. The measurement of environmental 
accounting in the development process in our country is very slow. Listed on the Shanghai Stock Exchange and Shenzhen Stock Exchange in the company's annual report, none of the companies in the annual report on environmental issues to make more or less information disclosure. Special daily accounting treatment, and the cost of environment is usually used as the conventional processing problem of financial accounting in the financial impact of the clear for example: pay sewage charges included in management fees; in violation of environmental regulations to pay fines and ordered to stop losses included in operating expenses; setting ring The expenditure of environmental agencies is included in the management cost. The investment of new equipment for reducing pollution and improving the environment is treated as a fixed asset expenditure. It can be seen that our environmental accounting and environmental information disclosure is relatively backward.

The knowledge structure of existing Accountants. Environmental accounting is accounting and environmental science and other disciplines such as the combination of sustainable development science disciplines, therefore requires the participation of technical personnel and personnel of environmental accounting, environmental accounting to carry out the requirements for accounting personnel is very comprehensive, but the accounting personnel of our country basically is from accounting, finance, audit and other related professional personnel knowledge, focus on accounting, financial and other aspects, to the environment, industry, sustainable development is the lack of knowledge, at the same time, the environmental technical personnel participation is not enough, which effectively carry out environmental accounting. So the accounting personnel must update its traditional knowledge structure, learning and mastering the knowledge of environmental science and environmental economics and understand the relationship between enterprise production and business environment. No one such knowledge structure, accounting personnel are unable to adapt to the requirements of environmental accounting, which will affect Sound the promotion and implementation of environmental accounting.

\section{The Cause of the Slow Development of Environmental Accounting in China}

Environmental accounting has not been paid enough attention in the field of accounting in China. That accounting of assets, liabilities, income in the traditional concept of people, cost accounting, environmental accounting that is just so. In fact, the environmental accounting is not the case, the environmental accounting from the interests of the entire social environment in terms of business activities, so that the accounting service object, from the traditional service as a business unit, to expand beyond the owners and shareholders other social groups and even the entire national economy.

Compared with the developed countries, our country is still in the stage of development, still taking economic development as the center. China has changed turn the world upside down in a few decades, people's living standard had a qualitative leap. At the population level, due to the very strong desire to build up the family fortunes, lack of entrepreneurial environment education related to the crowd environmental protection, environmental protection consciousness, will both pay no attention to environmental aspects; many large and medium-sized enterprises affected by the historical inertia and policy environment, often only pay attention to return on investment, less active attention to the development and application of environmental accounting. From the perspective of profit, environmental protection will increase the cost, reduce the short-term profits, so enterprises do not attach importance to environmental protection, causing serious damage and waste of natural resources, environmental pollution, the deterioration of the living environment and a series of problems.

The relevant laws and regulations are not sound. The lack of content of environmental accounting accounting law in China, promulgated by the environmental regulations also lack the content of environmental accounting, environmental accounting can not follow, corporate environmental accounting information disclosure in our country there is no uniform standard. No specific legal provisions of environmental crime, the environmental aspects of the illegal acts of punishment is not enough. The destruction of the environment of enterprises the punishment is far 
less than the income obtained by enterprises, which leads to some enterprises to break the law, for profit to risk destruction, pollution of the environment. Only to improve and perfect the relevant laws and regulations, so that enterprises can pay more attention to environmental issues and the leaders of enterprises, but also more conducive to the implementation of corporate environmental accounting.

The enterprise does not have the environmental protection as a necessary condition for the survival and development of enterprises. Enterprises do not have the environmental protection as the enterprise to expand market share, an important means of improving economic efficiency, environmental protection investment and technology that have no real returns, poor enthusiasm. In order to improve environmental performance, improve the environmental protection work effect. To ensure the sustainable development of human society, by means of accounting measurement and control of environmental resources, clear environmental responsibility, system of accounting method of special research is very necessary. But so far, China has not yet formed a system of environmental accounting information disclosure system, and the lack of environmental accounting standards is feasible, which makes the corporate disclosure environment the information is not sufficient and thorough and lack of comparability, is not conducive to the use of environmental information to stakeholders.

There is no real solution to the measurement of environmental accounting.Environmental accounting environmental assets, environmental cost, environmental benefits and other accounting elements for accounting content. The accounting elements of environmental accounting should adopt certain methods for currency conversion measurement. But the environmental accounting currency meaning is not entirely based on the above theory of labor value. According to the theory of labor value, only the exchange the commodity, its value can be measured by the social necessary labor time. For non exchange, non human labor goods is not measured, accounting does not need to calculate. However, these non - human labor goods exchange, there is considerable part of environmental accounting, environmental accounting must be established and is able to measure the non the exchange of goods, non human labor value theory.

The performance assessment system for implementing environmental accounting has not been established. Environmental factors did not consider the traditional performance appraisal system. Therefore, in order to introduce environmental accounting in the enterprise, the enterprise must make environmental awareness through all procedures and policies. Only all the members of the enterprise know enterprises under environmental obligations is necessary part of enterprise performance, so they will have environmental awareness, efforts to create environmental performance. Due to the late study of environmental accounting in our country, in the current accounting system has not been established accounting system and supporting the environmental cost, only in the enterprise "management fees" accounting set up "sewage charges" and "green" project, effective accounting difficult, thus restricting the environmental accounting I the development of country. It is generally considered that the basic theory of environmental accounting should be a goal, assumptions and principles of composition of system, the government should organize the relevant professional scholars as soon as possible. The family set up a theoretical system that conforms to the national conditions of our country and provides theoretical support for the development of China's environmental accounting.

Insufficient publicity for environmental protection. Our country compared with the developed country environmental education is relatively backward, weak awareness of environmental protection. The development and strengthening of environmental protection consciousness depend $\mathrm{s}$ on environmental education, environmental accounting implementation cannot do without awareness of environmental protection. Because of the green consumption consciousness, which makes the environmental accounting in our country. Now the slow development of the environmental consciousness of consumers although compared with the previous increase a lot, but on the whole is weak, the reason is mainly in the aspect of environmental protection publicity less. In addition, investor demand for environmental information is not large, the choice of investment 
enterprises, rarely focus on corporate environmental conditions and possible future environmental costs, thus to some extent. No enterprise realized the implementation of environmental accounting.

\section{The Strategies for the development of environmental accounting in China}

Strengthening the implementation of environmental accounting. The enterprise must carry out environmental accounting, environmental information disclosure to be fully credible, the public will really know the environmental conditions, the necessity and urgency to realize environmental protection. Therefore, in the process of establishment and development of environmental accounting, should overcome the shackles of the traditional concept, necessity and superiority vigorously promote environmental accounting, environmental accounting emphasizes the role in China's economic construction, strengthen environmental protection, promote harmony between man and nature; and optimize the industrial structure, the development of recycling economy, improve the legal system of environmental protection, strict environmental enforcement, strengthening environmental monitoring, regularly publish the state information of the environment. Enterprises to achieve long-term survival and steady development, must adapt the environment concept, not only to adapt to the social environment, but also to adapt to the natural environment. Enterprises in as much as possible to adapt to the social environment, to seek the best investment and financing environment, policy environment, to achieve long-term survival and steady development at the same time, to minimize waste emissions to in the environment; enterprises should have a stable natural environment as the material foundation, and harmony with the natural environment. The enterprises based on their own economic interests standpoint, should enhance the awareness of environmental protection, increase environmental protection investment, reduce energy consumption, environmental protection measure refinement of input and output. Through the measurement of the environmental resources are the responsibility of environmental protection and the environmental cost, enterprises have to confirm environmental gains or losses, so as to fully measure the benefit of the enterprise, realize the goal of enterprise for Provide real, reliable information.

Improve the relevant laws and regulations. The accounting law is the highest level of the accounting work regulations, environmental accounting supervision into the accounting law, in the form of law to establish the status and function of environmental accounting is the most powerful means of implementing environmental accounting. On the one hand, modify the accounting law, increase the content of environmental accounting terms; on the other hand, improve the accounting standards. The related content of environmental accounting in the accounting elements, the development of environmental accounting standards specific. And to develop specific accounting system, the accounting environment has operability, easy to master the practical application of accounting personnel, but also facilitate the accounting work.

Solving the measurement problems of environmental accounting. In the traditional accounting personnel should be measured in monetary terms, accounting supervision and accounting entity's production and business activities. Compared with the traditional accounting, environmental accounting is the object of environmental activities, there are many indicators in traditional accounting are very difficult to quantify the currency. Seen from the development process of the environmental accounting is not difficult, the key difficulty of their actions environmental information is not easy to confirm, not easy to measure, and it is very difficult to be revealed. Therefore, environmental accounting should be in line with the principle of gradual and orderly progress, the easy to measure and reveal the index into the enterprise accounting system of accounting.

Setting up an environmental performance appraisal system. Environmental performance evaluation of enterprise from the connotation of "high input, high consumption, high emission, difficult circulation, low efficiency" point of view, the environmental performance assessment refers to the promotion of circular economy and economical society construction, enterprise management to achieve a win-win goal of environmental performance and financial performance, efficiency and effect from environmental contributions to measure the enterprise resources, a 
comprehensive evaluation of environmental impact caused by the production and business activities of enterprises. It is an important basis for the implementation of the measure of corporate environmental policy, but also the precondition of enterprise environmental decision-making. Because of the environmental performance measurement, single environmental performance indicators are difficult to accurately reflect the influence of environment enterprises, therefore, need an environmental performance evaluation system of enterprise environmental performance evaluation.

Increasing publicity for environmental protection. In just a few decades, China has a qualitative leap, most knowledge is limited, the existing conditions, not aware of a potential environmental threat. And these potential threats to the environment, see the invisible is hurting the health of people. Such as radioactive substances and carcinogens. If people do not have such relevant knowledge, is not aware of the danger, will cause irreparable consequences. The environmental pollution in China is serious and widespread, it should raise the public awareness of environmental protection, the establishment of public participation mechanism, so that they can on the investment project planning and implementation of views and influence. If the environmental crisis and the concept of environmental protection can be popular, investors, financial institutions, market related parties, enterprises, the public to pay attention to environmental protection, enterprises should pay attention to environmental pollution and governance, to enable enterprises to ring Environmental information disclosure has become a common social requirement, people cry, then the implementation of environmental accounting will point the day and await for it.

\section{References}

[1] Gao Minfang. Obstacles and Countermeasures to implement environmental accounting in China, [J]. finance and accounting research, 2008 (2)

[2] Li Xinhe, Wang Yan, Chen Po. China accounting Xuhui environmental accounting symposium review [J]. accounting research, 2002 (1): 58-62

[3] Xu Jialin, Cai biography. China Retrospect and Prospect of the research on environmental accounting [J]. accounting research, 2004. (4): 87-92

[4] In Jingjing. How to set up the environmental accounting system in our country on the [J]. financial economy, 2009 (8)

[5] Song Shengju. Discussion on some problems of environmental accounting in China [J]. Journal of Hebei University of Economics and Business, 2009 (5)

[6] Wang Shaomei. The establishment and application of environmental accounting in China [J]. Journal of the economic academy of Shandong Province, 2003 (2) 